$5 / 2.14-95$ ys $(2)$

PREPARED FOR THE U.S. DEPARTMENT OF ENERGY, UNDER CONTRACT DE-AC02-76-CHO-3073

PPPL-3042

PPPL-3042

UC-420,426

\title{
FORMATION OF CORE TRANSPORT BARRIER AND CH-MODE BY ION BERNSTEIN WAVE HEATING IN PBX-M
}

\author{
BY
}

M. ONO, R. BELL, S. BERNABEI, ET AL.

JANUARY 1995

DISTRIBUTION OF THIS DOCUMENT IS UNLIMITED

$\left.\left.\int[] D\right] D\right]\left[\begin{array}{l}\text { PRINCETON } \\ \text { PLAgMA PHYSICS } \\ \text { LABGAATOAY }\end{array}\right.$

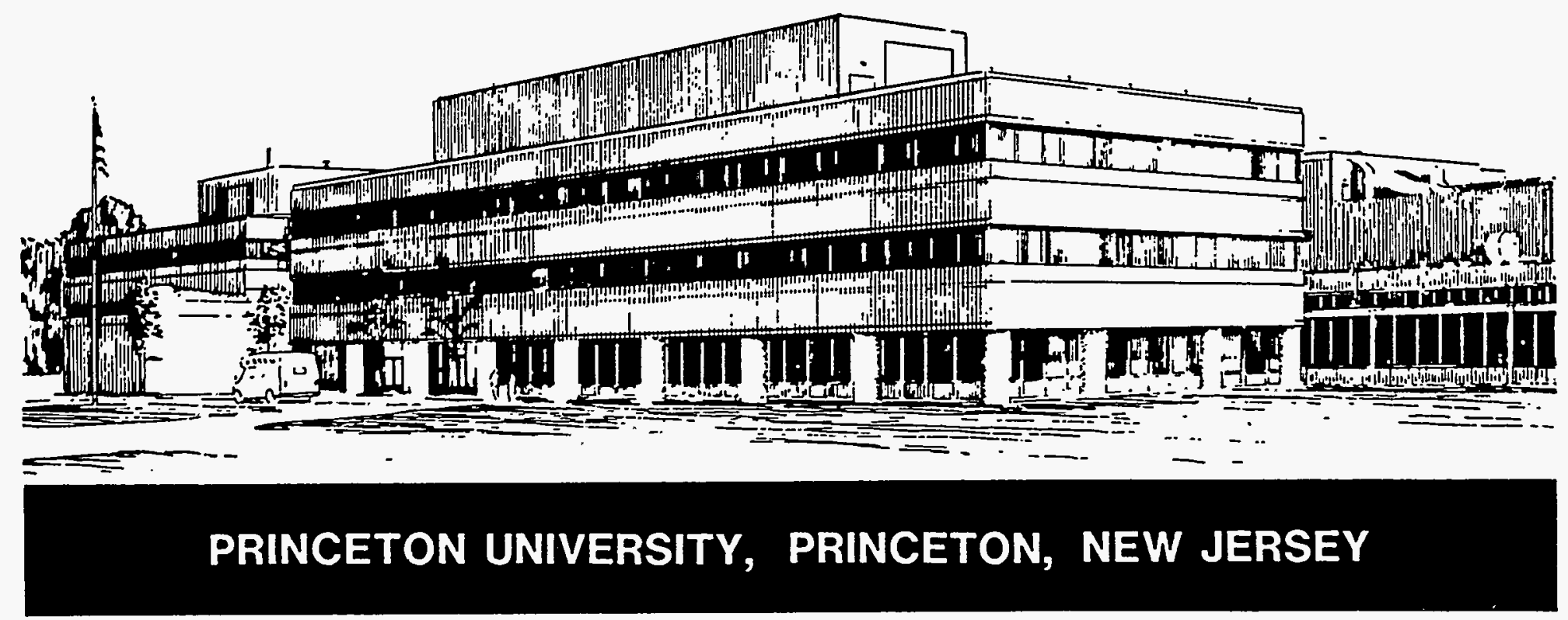




\section{NOTICE}

This report was prepared as an account of work sponsored by an agency of the United States Government. Neither the United States Government nor any agency thereof, nor any of their employees, makes any warranty, express or implied, or assumes any legal liability or responsibility for the accuracy, completeness, or usefulness of any information, apparatus, product, or process disclosed, or represents that its use would not infringe privately owned rights. Reference herein to any specific commercial produce, process, or service by trade name, trademark, manufacturer, or otherwise, does not necessarily constitute or imply its endorsement, recommendation, or favoring by the United States Government or any agency thereof. The views and opinions of authors expressed herein do not necessarily state or reflect those of the United States Government or any agency thereof.

\section{NOTICE}

This report has been reproduced from the best available copy. Available in paper copy and microfiche.

Number of pages in this report: 14

DOE and DOE contractors can obtain copies of this report from:

Office of Scientific and Technical Information

P.O. Box 62

Oak Ridge, TN 37831 ;

(615) $576-8401$.

This report is publicly available from the:

National Technical Information Service

Department of Commerce

5285 Port Royal Road

Springfield, Virginia 22161

(703) $487-4650$ 


\section{DISCLAIMER}

Portions of this document may be illegible in electronic image products. Images are produced from the best available original document. 
FORMATION OF CORE TRANSPORT BARRIER AND CH-MODE BY ION BERNSTEIN WAVE HEATING IN PBX-M

M. ONO, R. BELL, S. BERNABEI, G. GETTELFINGER, R. HATCHER, R.

KAITA, S. KAYE, H. KUGEL B. LeBLANC, J. MANICKAM, M. OKABAYASHI, S. PAUL, P. RONEY, N. SAUTHOFF, S. SESNIC, H.

TAKAHASHI, W. TIGHE, J. TIMBERLAKE, S. VON GOELER

Princeton Plasma Physics Laboratory, Princeton University, P.O. Box 451, Princeton, New Jersey 08543, USA,

J. DUNLAP, A. ENGLAND, J. HARRIS, R. ISLER, A. POST-ZWICKER Oak Ridge National Laboratory, TN, USA.

L. BLUSH, R. CONN, R. DOENER, Y. HIROOKA, L. SCHMITZ, G. TYNAN, UCLA, Calif., ÚSA.

E. DE LA LUNA, I. GARCIA, J. SANCHEZ CIEMAT, Madrid, Spain

S. BATHA, F. LEVINTON, Fusion Physics and Technology, Torrance, Calif., USA

S. LUCKHARDT, F. PAOLETTI, P. WOSKOV, A. ZOLFAGHARI Massachusetts Institute of Technology, Cambridge, Mass., USA

T. MUTOH, T. SEKI, NIFS, Japan

N. ASAKURA, JAERI, JAPAN,

A. CARDINALI, and R. CESARIO, ENEA, Frascati, Italy

G. PETRAVICH, Hungarian Academy of Sciences, Budapest, Hungary

M. TALVARD, CEN-Cadarache, France

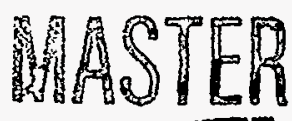

DISTRIBUTION OF THIS DOCUMENT IS UNLIMITED 


\title{
FORMATION OF CORE TRANSPORT BARRIER AND CH-MODE BY ION BERNSTEIN WAVE HEATING IN PBX-M
}

\begin{abstract}
Observation of core transport barrier formation (for particles, ion and electron energies, and toroidal momentum) by ion Bernstein wave heating (IBWH) in PBX-M plasma is reported. The formation of a transport barrier leads to a strong peaking and significant increase of the core pressure $(70 \%)$ and toroidal momentum (20\%), and has been termed the corehigh confinement mode ( $\mathrm{CH}-\mathrm{Mode}$ ). This formation of a transport barrier is consistent, in terms of the expected barrier location as well as the required threshold power, with a theoretical model based on the poloidal sheared flow generation by the ion Bernstein wave power. The use of ion Bernstein wave (IBW) induced sheared flow as a tool to control plasma pressure and bootstrap current profiles shows a favorable scaling for the use in future reactor grade tokamak plasmas.
\end{abstract}

\section{INTRODUCTION}

Plasma pressure control is an important issue for advanced tokamak regimes [1]. It is particularly crucial when one considers high-performance tokamak plasmas where high- $\beta$ plasmas are sustained almost entirely by selfgenerated bootstrap currents. For example, by properly aligning the bootstrap current to insure stability against ballooning and kinetic modes, an attractive high-performance regime with a negative magnetic shear region has been recently proposed [2]. To insure proper "alignment" of the bootstrap current, it is important to develop a tool to control the plasma pressure profile. If one looks toward burning plasmas with several hundred MW of $\alpha$-heating power, transport control represents a powerful tool for pressure profile control.

\section{PHYSICS OF POLOIDAL SHEARED FLOW GENERATION BY IBW}

To develop an efficient tool for active transport control, a concept based on $\mathrm{RF}$-induced sheared flow generation has been proposed $[3,4]$. In an $\mathrm{H}$ mode related theory, the generation of sufficient sheared poloidal flow is predicted to stabilize turbulence thereby improving confinement [5]. The nonlinear sheared flow, $d V_{p} / d r$, for each ion species in the presence of the IBW electric field $\tilde{E}_{\perp}$ can be given as

$$
\frac{d V_{p}}{d r}=\frac{d}{d r}\left[(\tilde{V} \cdot \nabla) \tilde{V}_{p} \mu_{n e o}^{-1}\right]=\frac{d}{d r}\left[\mu_{n e o}^{-1} \sum_{r a y s-j} a_{j} b_{j} \tilde{E}_{\perp j}^{2} k_{r, j} \operatorname{sgn}\left(k_{r}\right)\right]
$$

where $\mu_{\text {neo }}$ is the neoclassical ion viscosity damping term, $\tilde{V}$ is the ion oscillation velocity vector, $a_{j}$ and $b_{j}$ are the ion response functions, and $s g n$ - $r_{r} \cdot !\left(k_{r}\right)$ is $+1+$ for the radially inward propagating ray and -1 for the outward 
propagating ray. The subscript summation $\mathrm{j}$ represents the wave rays used in ray tracing calculations. The generated momentum drive, summed over all ion species, is then averaged within each flux surface grid. The sheared flow is generated strongly near the wave power absorption region since $d / d r=-2$ Im $\mathrm{k}_{\mathrm{r}}$. The combination of high wave electric fields, large ion response functions, high wave number (which is enhanced near the absorption region), and strong local wave absorption all contribute to make the poloidal sheared flow significant for IBW. In Fig. 1, typical IBW ray trajectories, the absorbed wave power density, and the calculated velocity shear are shown [see Ref. 6 for a general review of IBWH]. With only a relatively modest power of 300 $\mathrm{kW}$, a significant sheared flow $\geq 10^{5} \mathrm{sec}^{-1}$ is generated. This level of shear is believed to be sufficient for turbulence suppression. It should be noted that if the wave absorption is weak, the sheared flow is expected to be small, since Im $k_{r}$ is small and the effect of inward $k_{r}$ and outward $k_{r}$ [see Eq. (1)] tend to cancel .

\section{OBSERVATION OF CORE TRANSPORT BARRIER AND CH- MODE}

TIME EVOLUTION OF CH-MODE DISCHARGE - Application of $\mathrm{IBW}$ power $\left(\mathrm{P}_{\mathrm{IBW}} \approx 300 \mathrm{~kW}\right.$ ) in a strongly-NBI heated $\mathrm{H}$-mode plasma $\left(\mathrm{PNBI}_{\mathrm{NB}} \approx 2 \mathrm{MW}\right)$ causes a strong peaking of the pressure profile in beanshaped PBX-M plasmas, termed the $\mathrm{CH}-$ Mode (Core High confinement Mode)[7]. In Fig. 2, the evolution of a CH-Mode discharge is shown. The IBW power is applied during a pre-existing $\mathrm{H}$-mode. The discharge goes through an initial ELM (Edge-Localized-Modes) phase, which then evolves into the ELM-free CH-mode phase. Even though the line integrated density is relatively flat, the central density increases significantly. In the figure, the time evolution of the density peakedness, $n_{e}(0) /\left\langle n_{e}\right\rangle$, as computed from TVTS, is also shown. The peakedness rises from 1.5 for the H-mode to 2.5 2.7 for the $\mathrm{CH}$-mode.

PROFILE COMPARISON OF CH-MODE AND H-MODE - A comparison of the various plasma profiles (at $\mathrm{t}=600 \mathrm{msec}$ ) during the $\mathrm{CH}$ mode (with IBW) and H-mode (without IBW) is shown in Fig. 3. Two discharges are similar except for the presence of $\approx 300 \mathrm{~kW}$ of IBW power. In Fig. 3(a) and 3(b), the measured 51 point TVTS $T_{e}$ and $n_{e}$ profiles, both taken at the same discharge time, are shown for the $\mathrm{CH}$-mode and $\mathrm{H}$-mode (without IBW) for otherwise identical discharges. A strong contrast is seen in the density profiles, where the density is strongly peaked for the $\mathrm{CH}$-mode with the central density nearing $10^{14} \mathrm{~cm}^{-3}$, while for the $\mathrm{H}$-mode, it remains relatively flat not exceeding $6 \times 10^{13} \mathrm{~cm}^{-3}$. The electron temperature profile for the $\mathrm{CH}$-mode has the distinctive feature of a steep slope near the mid-plane radius of $\mathrm{r} \approx 13 \mathrm{~cm}$. In Fig. 4 (c) and (d), the ion temperature and toroidal rotation velocity, $V_{\phi}$, profiles from the charge-exchange recombination spectroscopy (CHERS) diagnostics are shown. Both show an increase in the 
core region. This peaking of the $\mathrm{n}_{e}, \mathrm{~T}_{e}, \mathrm{~T}_{\mathrm{i}}$, and $\mathrm{V}_{\phi}$ profiles results in a significant increase in the core plasma pressure $(\approx 70 \%)$ and a significant enhancement of toroidal velocity $(20 \%)$ for the $\mathrm{CH}$-mode compared to the $\mathrm{H}$ mode. The peaking of the pressure and $\mathrm{V}_{\phi}$ profiles in the $\mathrm{CH}$-mode is primarily due to a transport change in the mid-radius region, since the applied IBW power is very modest compared to the total heating power, PIBW $<$ PNBI. TRANSP analyses of these discharges indeed confirm that a factor of two reduction in the ion energy and toroidal momentum diffusivities in the core region (near the mid-radius) occurs during the $\mathrm{CH}$-mode, compared to the ELM-free phase of $\mathrm{H}$-mode. The core particle diffusivity also shows a large drop compared to the $\mathrm{H}$-mode. The electron diffusivity behavior is not conclusive due to the uncertainty in the measured radiated power. We shall discuss this formation of a transport barrier in more detail in Sec. IV.

SOFT X-RAY BARRIER OBSERVATION - Additional insight into the electron energy barrier formation is provided by the 32-channel vertical soft X-ray diagnostic during the earlier ELM phase of the discharge (even before the profile peaking) [8]. In a typical PBX-M H-mode discharge, during the ELM, the soft X-ray intensity generally drops in the plasma interior and increases in the edge, indicating the outward loss of electron thermal energy. Shortly after the IBW power reached its full value $(\approx 10-15 \mathrm{msec})$, the soft $X$ ray data show formation of a transport barrier observed near the vertical position of $\mathrm{z} \approx 17 \mathrm{~cm}$, which corresponds to a mid-plane position of $\mathrm{r} \approx 11-13$ $\mathrm{cm}$. This barrier location coincides reasonably well with the position of the steep kinetic gradient region later formed in the $\mathrm{CH}$-phase (see Sec. IV). It should be noted that the barrier may be weakened by ELM activity. When ELMS occur in rapid succession (e.g., for the case where the ELM bursts occur $\approx 1 \mathrm{msec}$ apart), the observed barrier becomes progressively weaker. The barrier grows stronger when the ELM quiescent period is longer (e.g., $\approx 7$ $\mathrm{msec}$ ). As the discharge enters an ELM-free period, the full barrier quickly develops (as indicated by the $\mathrm{CH}$-Mode period). During the $\mathrm{CH}$-mode period, sawteeth and ELMs are absent.

ENHANCED NEUTRON YIELDS AND BOOTSTRAP CURRENT REALIGNMENT - To take advantage of the improved core confinement, two additional neutral beams (total of $\approx 4 \mathrm{MW}$ ) were injected during the $\mathrm{CH}$ mode phase. Even though the heating power was nearly doubled, the essential features of the $\mathrm{CH}$-mode were preserved. With the additional heating power, the (H-mode) edge barrier is again restored as seen by the soft $X$-ray diagnostic, the profile showing two barriers. The steep density gradient in the mid-radius region of the $\mathrm{CH}$-mode resulted in a doubling (jboot fraction reaching $35 \%$ ) of the bootstrap current generation in the half-radius region (estimated from the TVTS profiles) compared to the H-mode case. Perhaps more importantly, the $\mathrm{CH}$-mode was able to move the bootstrap current region away from the edge for the $\mathrm{H}$-mode case toward the core region, which leads to a more desirable bootstrap current profile alignment [2]. The bootstrap 
current (driven off-axis) tends to increase the central $q(0)$. The measured $q(0)$ with the MSE diagnostic rises in the density rising phase from 0.8 to .97 , which is consistent with the TRANSP values. In addition, the peaked $\mathrm{CH}$ mode discharges generally resulted in a significant enhancement of the D-D beam target fusion neutron yield (up to $60 \%$ ) compared to otherwise similar $\mathrm{H}$-mode discharges. This result indicates that IBW is highly efficient in maintaining the $\mathrm{CH}$-mode with only a modest amount of $\mathrm{IBW}$ power, $\mathrm{P}_{\mathrm{IBW}} \approx$ $300 \mathrm{~kW} \ll \mathrm{P}_{\mathrm{NBI}} \approx 4 \mathrm{MW}$, a promising result for future applications.

\section{COMPARISON OF TRANSPORT BARRIER FORMATION AND SHEARED FLOW MODEL}

\section{OBSERVED BARRIER LOCATIONS AND SHEARED FLOW} LOCATION - The radial profiles of the absolute values of the $\mathrm{T}_{\mathrm{e}}, \mathrm{T}_{\mathrm{i}}$ and $\mathrm{n}_{\mathrm{e}}$ gradients are shown in Fig. 4(a). The H-mode has a strong density gradient in the edge region. For the $\mathrm{CH}$-mode, the strong density gradient region is moved well into the plasma core. The $\mathrm{CH}$-mode also has a strong electron temperature gradient in the core region $(\mathrm{r} \approx 13 \mathrm{~cm})$, well above the experimental error bars. These large gradients suggest the existence of an $\mathrm{H}$ mode-like transport barrier near the mid-radius region. Similar gradients can be also seen in the ion temperature profile. The observed location of the soft $X$-ray ELM barrier $(\mathrm{r} \approx 11-13 \mathrm{~cm}$ ) is indicated in the figure. In the strong pressure gradient region, ballooning-like high frequency $(75-350 \mathrm{kHz}) \mathrm{MHD}$ fluctuations are observed. In Fig. 4(b), the $V_{\phi}$ gradient and the calculated IBW induced poloidal sheared flow are shown with their locations coinciding relatively well with the observed barrier location. The $\mathrm{T}_{\mathrm{e}}$ gradient appears to occur at a slightly larger radius than the rest of the barrier locations. It might be conjectured that the $T_{e}$ gradient may be influenced by the presence of the nearby $\mathrm{q}=3 / 2$ surface.

RESONANT vs. NON-RESONANT HEATING EXPERIMENT - In PBX-M IBW experiments, the peaking of density was observed not only in the $\mathrm{CH}$-mode but also in the ohmic discharges. In a typical ohmic discharge, an application of a modest amount IBW power $(100 \mathrm{~kW})$ for $5 \Omega \mathrm{D}$ resonance heating is usually sufficient to cause the density peaking. Also in the previous IBW experiments in JIPPTII-U, $3 \Omega_{\mathrm{H}}$ resonance heating caused peaking of density and pressure profiles in the $\mathrm{OH}$ and NBI heated L-mode circular plasmas [9]. Therefore, the profile peaking by IBWH appears to be associated with the presence of a resonant absorption layer in the plasma. The occurrence of peaking for the case with strong wave absorption is consistent with the sheared flow model. In addition, the observed required power in PBX-M for the density peaking is on the order of $100 \mathrm{~kW}$ (for circular Ohmic parameters) and $300 \mathrm{~kW}$ (for bean-shaped $\mathrm{CH}$-mode parameters), which is consistent with the estimated required IBW power based on the sheared flow model. In one experiment with a circular ohmic plasma in PBX-M, by going down to the lower cyclotron harmonic frequency $\left(\omega<4 \Omega_{\mathrm{D}}\right)$ by reducing the 
transmitter frequency to $42 \mathrm{MHz}$, the IBW ion cyclotron heating layer was moved to the high field side of the plasma. This configuration makes the heating layer inaccessible to the externally launched IBW, since in this case, the IBW rays are radially reflected near the plasma axis, and they propagate back towards the antenna essentially undamped. As mentioned in Sec. II, the inward and outward going waves tend to cancel the poloidal drive and therefore, little sheared flow is expected. Indeed, in this case, even with repeated attempts (over 100 shots) and with higher IBW power $(\approx 200 \mathrm{~kW})$, no peaking of the density profiles was observed (no local transport change), further supporting the sheared flow model.

FUTURE PROSPECTS AND EXPERIMENTAL PLANS - In terms of the plasma and device parameters, it can be shown from Eq. (1) that the generated poloidal sheared flow scales as

$$
\frac{\partial V_{p}}{\partial r} \propto \frac{B_{0} T_{i}^{0.5} P_{r f}}{\Delta r r^{2} n_{0}^{2} \sqrt{\kappa} Z_{e f f}^{2}} f\left(N_{i}, \frac{\omega}{\Omega_{i}}\right)
$$

where $\Delta r$ is the power deposition radial width, $\kappa$ is plasma elongation and $N_{i}$ is the ion species fractions. This scaling tends to favor high field, high temperature clean plasmas, offsetting the unfavorable inverse density and size scaling for future reactor grade plasmas. The model indeed predicts high poloidal sheared flow generation efficiency by IBW in reactor-grade plasmas (e.g., for ITER parameters, $P_{I B W} \approx 10 \mathrm{MW} \ll P_{\alpha}$.) Since the wave absorption layer position can be varied by moving the ion cyclotron harmonic layer position (by changing the wave frequency or the magnetic field), it may lead to a tool for active plasma pressure and bootstrap current profile control, which is essential for advance tokamaks such as TPX and DEMO. The peaking of density and pressure profiles could also benefit ITER by enhancing fusion reactivity. On PBX-M, it is planned to explore further the physics of IBW induced sheared flow through poloidal velocity and plasma fluctuation measurements along with bootstrap current alignment studies. To enhance the quality of the $\mathrm{CH}$-mode on PBX-M, it is planned to increase the IBW power (possibly with two wave frequencies) and improve impurity control (e.g., wall boronization).

\section{ACKNOWLEDGMENT}

We thank the PBX-M and RF technical staff for making those experiments possible. We also thank J. R. Wilson, R. Hawryluk, and K. McGuire for helpful comments. Work is supported by the U.S. Department of Energy contract No. DE-AC02-76-CHO-3073. 


\section{REFERENCES:}

[1] GOLDSTON, R. J., et al., in Proceedings of the 20th European Conference on Controlled Fusion and Plasma Physics, Lisbon, 1993 (European Physical Society, Lisbon, Portugal, 1993) p. I-319.

[2] KESSEL, C., MANICKAM, J., REWOLDT, G., TANG, W. M., Phys. Rev. Lett. 72 (1994) 1212.

[3] CRADDOCK, G.G., DIAMOND, P.H.. Phys. Rev. Lett. 67 (1991) 1535.

[4] BIGLARI, H., ONO, M., DIAMOND, P. H., CRADDOCK, G. G., in proceedings of Ninth Topical Conference on Radio-Frequency Power in Plasmas (Charleston, 1991), AIP Conference Proceedings 244 (New York, 1992) 376.

[5] BIGLARI, H., DIAMOND, P.H., TERRY, P.W., Phys. Fluids B2 (1990) 1 .

[6] ONO, M., Phys. Fluids B 5 (1993) 241.

[7] LeBLANC, B. P., et al., Bull. Am. Phys. Soc. 38 (1993) 1959.

[8] SESNIC, S., et al., in <Proceedings of the Fifteenth International Conference on Plasma Physics and Controlled Nuclear Fusion Research>, (Seville, Spain, September 1994) (International Atomic Energy Agency, Vienna, Austria), IAEA-CN-60/A3/5-P-12.

[9] SEKI, T., KUMAZAWA, R., WATARI, T., et al., Nuclear Fusion, 32 (1992) 2189.

\section{FIGURE CAPTIONS}

Fig. 1. IBW induced sheared flow. (a) IBW ray-trajectories in PBX-M using the $\mathrm{CH}$-mode parameters. (b) Calculated sheared flow. $\mathrm{P}_{\mathrm{IBW}}=300 \mathrm{~kW}, \mathrm{BT}$ $=1.49 \mathrm{~T}(\mathrm{R}=165 \mathrm{~cm}), \mathrm{f}(\mathrm{IBW})=55 \mathrm{MHz}$.

Fig. 2. Time evolution of the $\mathrm{CH}$-mode discharge.

Fig. 3. $\mathrm{T}_{\mathrm{e}}, \mathrm{n}_{\mathrm{e}}, \mathrm{T}_{\mathrm{i}}$, and $\mathrm{V}_{\phi}$ profiles for the $\mathrm{CH}$-mode (solid) and $\mathrm{H}$-mode (light). $\mathrm{P}_{\mathrm{IBW}} \approx 300 \mathrm{~kW}, \mathrm{PNBI}_{2} \approx 2.0 \mathrm{MW}, \mathrm{BT}=1.49 \mathrm{~T}(\mathrm{R}=165 \mathrm{~cm}), \mathrm{f}$ $(\mathrm{IBW})=55 \mathrm{MHz}$.

Fig. 4. Composite of radial profiles of gradients (density, ion and electron temperatures, and toroidal rotation), the observed location of electron energy barrier by soft X-ray (indicated by an arrow), and the calculated poloidal sheared flow. 

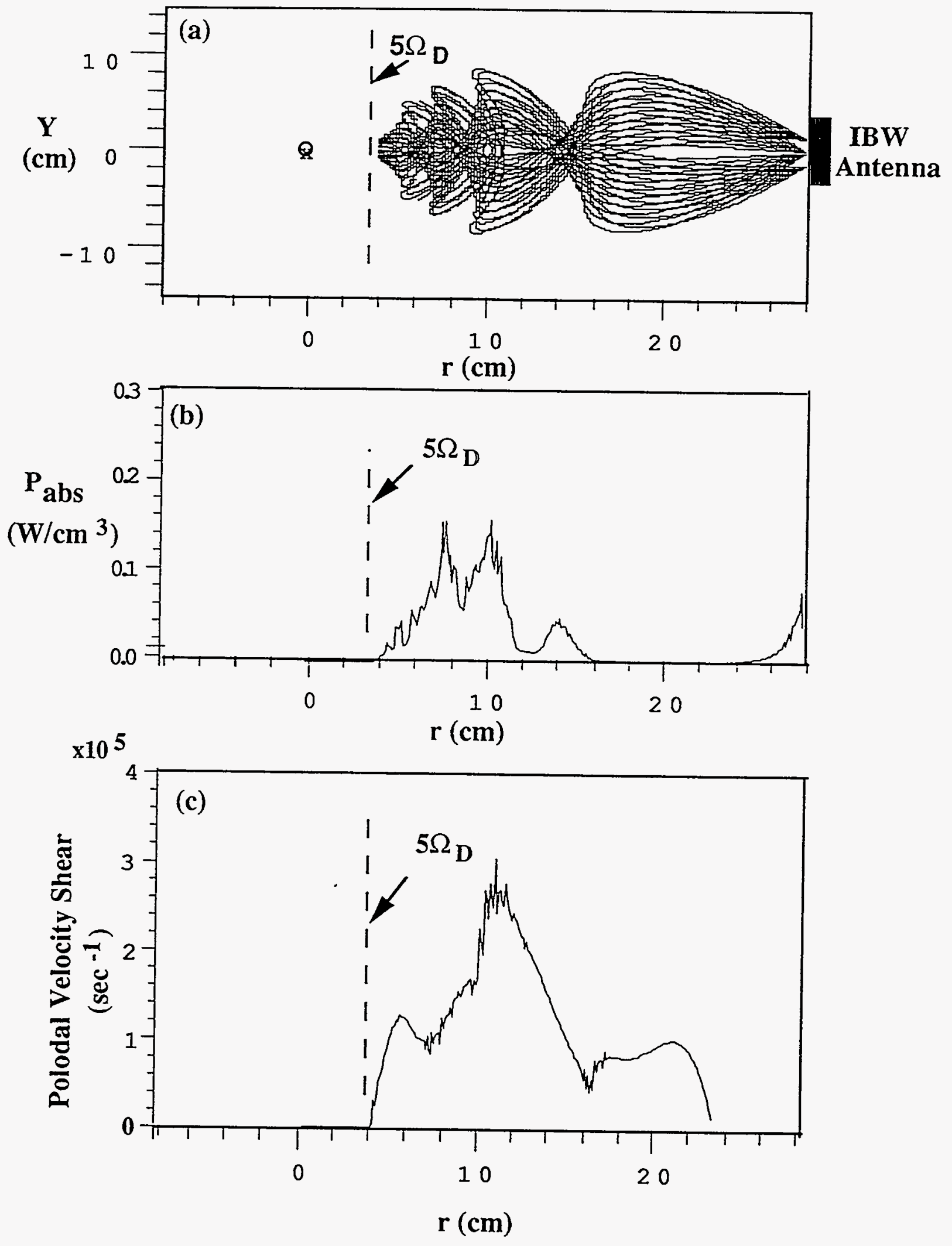

Fig. 1 


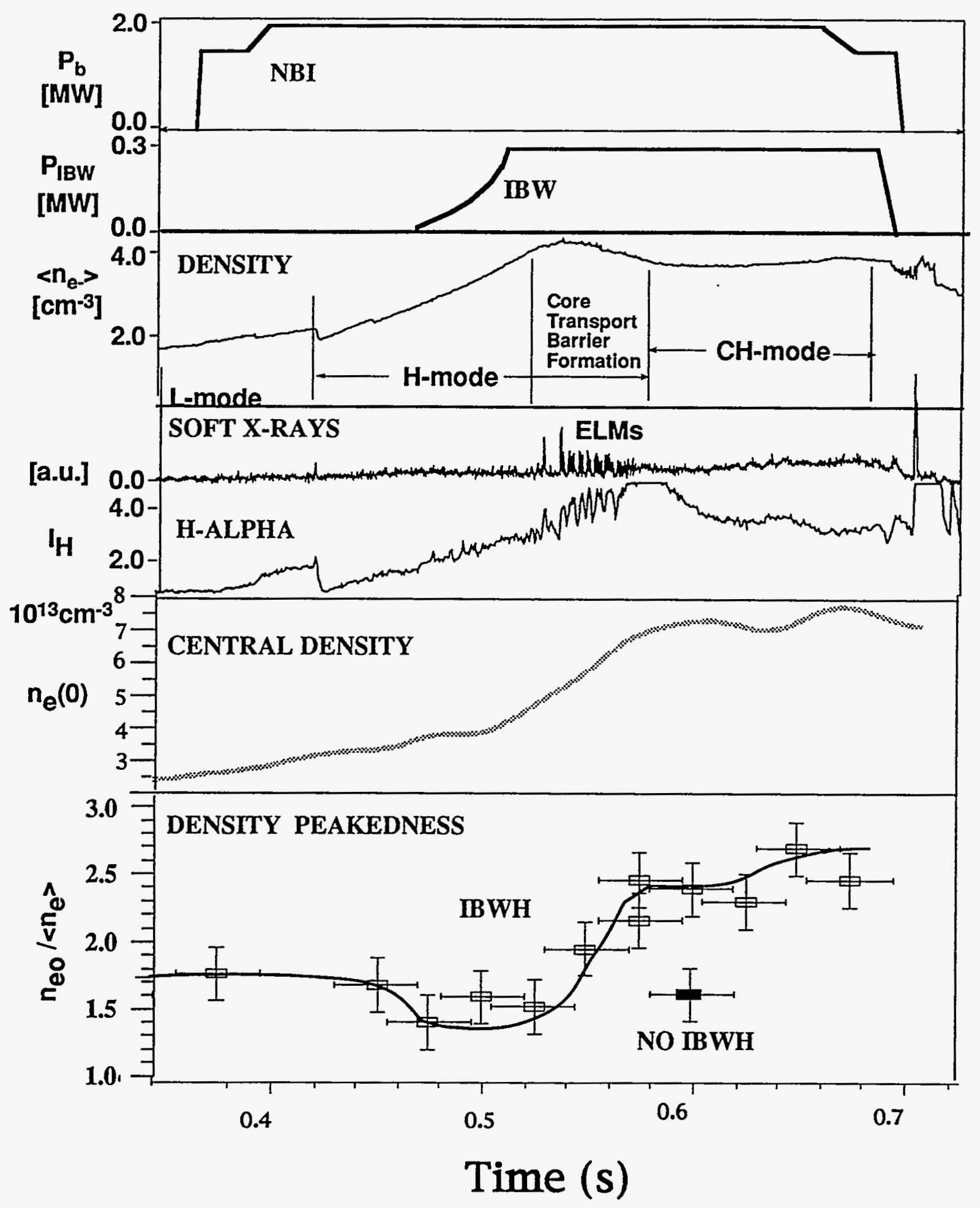

Fig. 2 

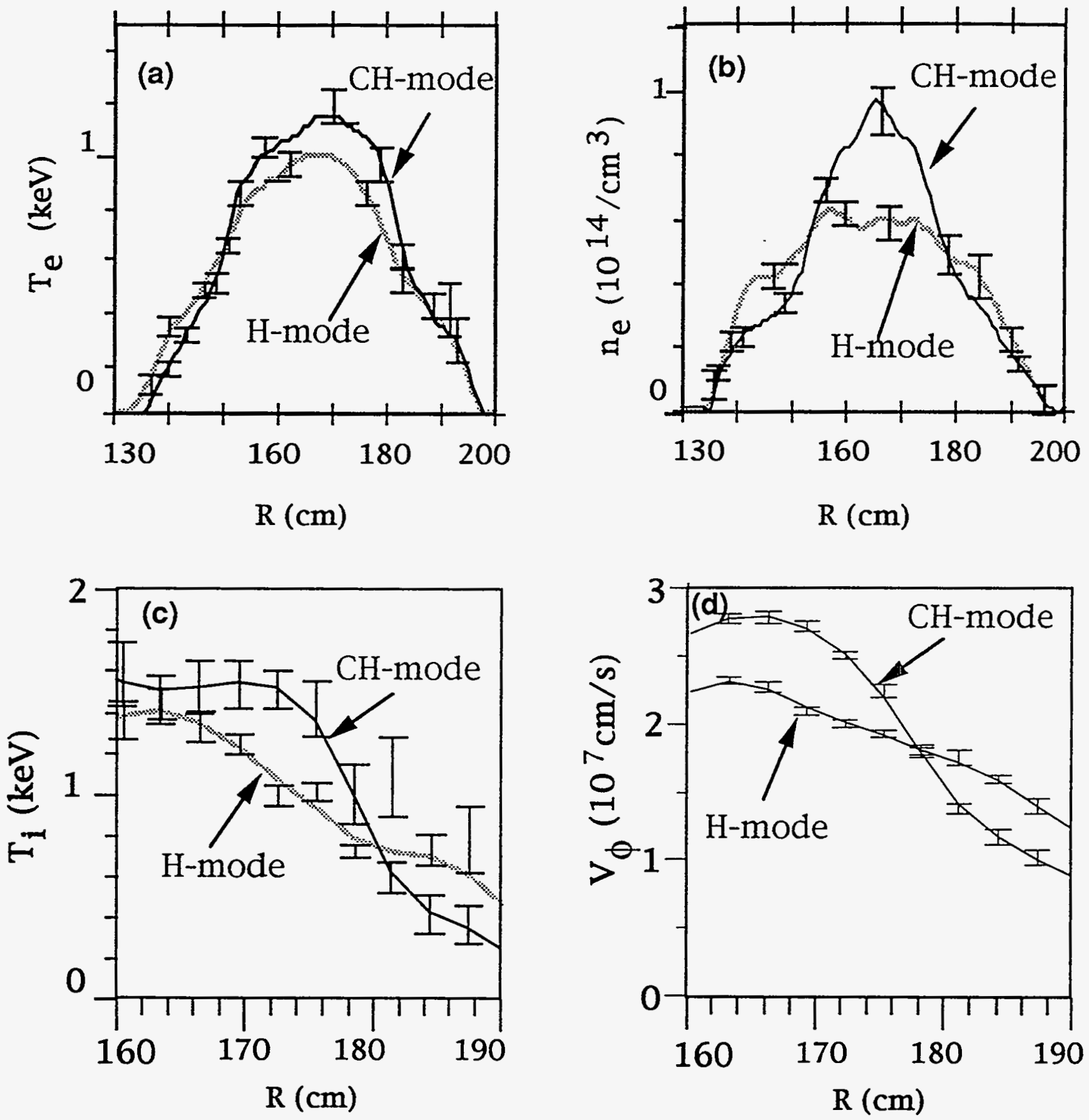

Fig. 3 

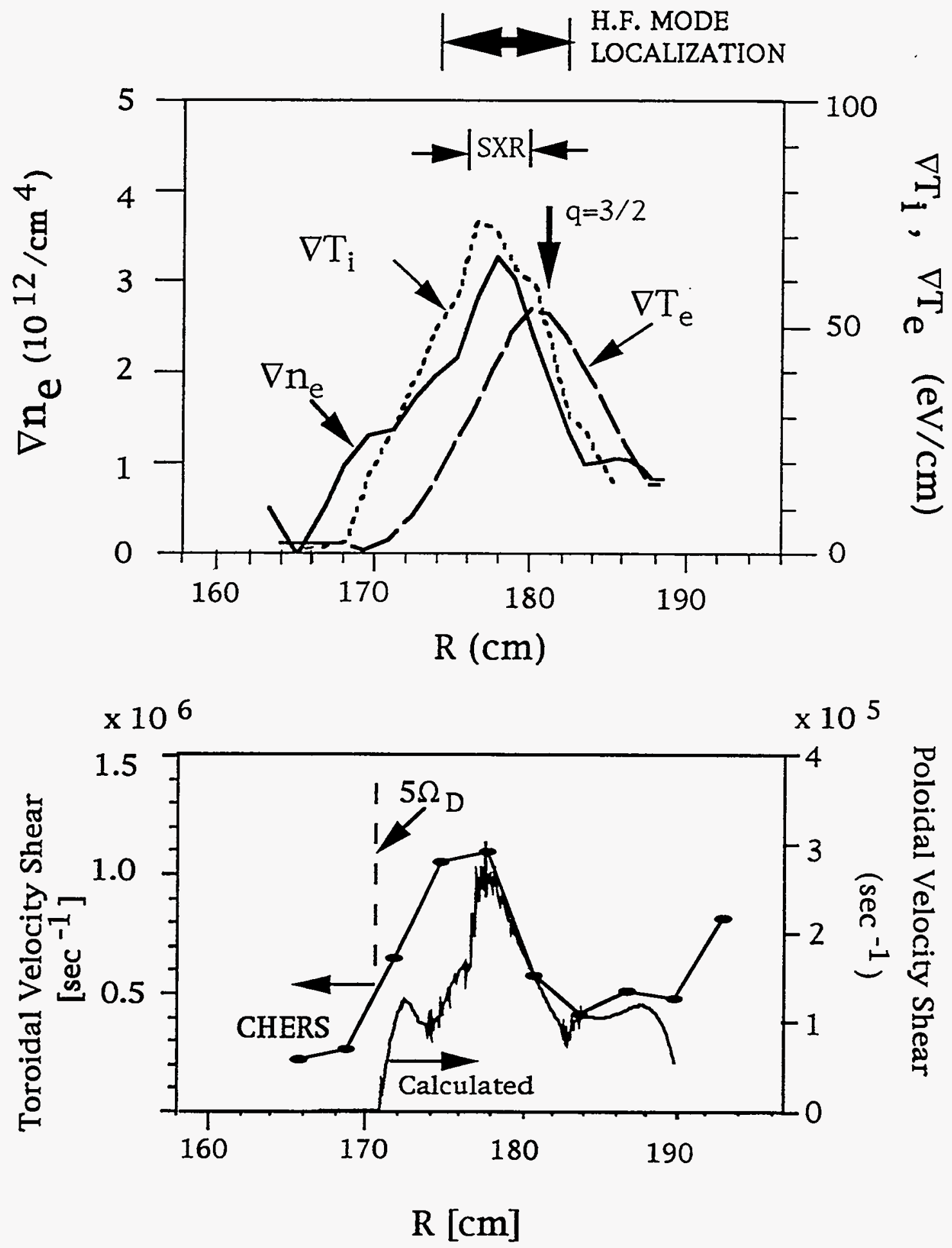

Fig. 4 


\section{EXTERNAL DISTRIBUTION IN ADDITION TO UC-420}

Dr. F. Paoloni, Univ. of Wollongong, AUSTRALIA

Prof. R.C. Cross, Univ. of Sydney, AUSTRALIA

Plasma Research Lab., Australian Nat. Univ., AUSTRALIA

Prof. I.R. Jones, Flinders Univ, AUSTRALIA

Prof. F. Cap, Inst. for Theoretical Physics, AUSTRIA

Prof. M. Heindler, Institut tür Theoretische Physik, AUSTRIA

Prof. M. Goossens, Astronomisch Instituut, BELGIUM

Ecole Royale Militaire, Lab. de Phy. Plasmas, BELGIUM

Commission-European, DG. XII-Fusion Prog., BELGIUM

Prof. R. Bouciqué, Rijksuniversiteit Gent, BELGIUM

Dr. P.H. Sakanaka, Instituto Fisica, BRAZIL

Prof. Dr. I.C. Nascimento, Instituto Fisica, Sao Paulo, BRAZIL Instituto Nacional De Pesquisas Espaciais-INPE, BRAZIL

Documents Office, Atomic Energy of Canada Ltd., CANADA

Ms. M. Morin, CCFMTokamak de Varennes, CANADA

Dr. M.P. Bachynski, MPB Technologies, Inc., CANADA

Dr. H.M. Skarsgard, Univ. of Saskatchewan, CANADA

Prot. J. Teichmann, Univ. of Montreal, CANADA

Prof. S.R. Sreenivasan, Univ. of Calgary, CANADA

Prof. T.W. Johnston, INRS-Energie, CANADA

Dr. R. Bolton, Centre canadien de fusion magnétique, CANADA

Dr. C.R. James, Univ. of Alberta, CANADA

Dr. P. Lukác, Komenského Universzita, CZECHO-SLOVAKIA

The Librarian, Culham Laboratory, ENGLAND

Library, R61, Rutherford Appleton Laboratory, ENGLAND

Mrs. S.A. Hutchinson, JET Library, ENGLAND

Dr. S.C. Sharma, Univ. of South Pacific, FIJI ISLANDS

P. Mähönen, Univ. of Helsinki, FINLAND

Prof. M.N. Bussac, Ecole Polytechnique, FRANCE

C. Mouttet, Lab. de Physique des Milieux lonisés, FRANCE

J. Radet, CEN/CADARACHE - Bat 506, FRANCE

Prof. E. Economou, Univ. of Crete, GREECE

Ms. C. Rinni, Univ. of loannina, GREECE

Preprint Library, Hungarian Academy of Sci., HUNGARY

Dr. B. DasGupta, Saha Inst. of Nuclear Physics, INDIA

Dr. P. Kaw, Inst. for Plasma Research, INDIA

Dr. P. Rosenau, israel inst. of Technology, ISRAEL

Librarian, Intemational Center for Theo Physics, ITALY

Miss C. De Palo, Associazione EURATOM-ENEA , ITALY

Dr. G. Grosso, Istituto di Fisica del Plasma, ITALY

Prof. G. Rostangni, Istituto Gas lonizzati Del Cnr, ITALY
Dr. H. Yamato, Toshiba Res \& Devel Center, JAPAN

Prof. I. Kawakami, Hiroshima Univ., JAPAN

Prof. K. Nishikawa, Hiroshima Univ., JAPAN

Librarian, Naka Fusion Research Establishment, JAERI, JAPAN

Director, Japan Atomic Energy Research Inst., JAPAN

Prof. S. Itoh, Kyushu Univ., JAPAN

Research Info. Ctr., National Instit. for Fusion Science, JAPAN

Prof. S. Tanaka, Kyoto Univ., JAPAN

Library, Kyoto Univ., JAPAN

Prot. N. Inove, Univ. of Tokyo, JAPAN

Secretary, Plasma Section, Electrotechnical Lab., JAPAN

Dr. O. Mitarai, Kumamoto Inst. of Technology, JAPAN

Dr. G.S. Lee, Korea Basic Sci. Ctr., KOREA

J. Hyeon-Sook, Korea Atomic Energy Research Inst., KOREA

D.I. Choi, The Korea Adv. Inst. of Sci. \& Tech., KOREA

Prof. B.S. Liley, Univ. of Waikato, NEW ZEALAND

Inst of Physics, Chinese Acad Sci PEOPLE'S REP. OF CHINA

Library, Inst. of Plasma Physics, PEOPLE'S REP. OF CHINA

Tsinghua Univ. Library, PEOPLE'S REPUBLIC OF CHINA

Z. Li, S.W. Inst Physics, PEOPLE'S REPUBLIC OF CHINA

Prof. J.A.C. Cabral, Instituto Superior Tecnico, PORTUGAL

Prof. M.A. Hellberg, Univ. of Natal, S. AFRICA

Prof. D.E. Kim, Pohang Inst. of Sci. \& Tech., SO. KOREA

Prof. C.I.E.M.A.T, Fusion Division Library, SPAIN

Dr. L. Stenflo, Univ. of UMEA, SWEDEN

Library, Royal Inst. of Technology, SWEDEN

Prof. $H$. Wilhelmson, Chalmers Univ. of Tech., SWEDEN

Centre Phys. Des Plasmas, Ecole Polytech, SWITZERLAND

Bibliotheek, Inst. Voor Plasma-Fysica, THE NETHERLANDS

Asst. Prof. Dr. S. Cakir, Middle East Tech. Univ., TURKEY

Dr. V.A. Glukhikh,Sci. Res. Inst. Electrophys.I Apparatus, USSR

Dr. D.D. Ryutov, Siberian Branch of Academy of Sci., USSR

Dr. G.A. Eliseev, I.V. Kurchatov Inst., USSR

Librarian, The Ukr.SSR Academy of Sciences, USSR

Dr. L.M. Kovrizhnykh, Inst. of General Physics, USSR

Kernforschungsanlage GmbH, Zentralbibliothek, W. GERMANY

Bibliothek, Inst. Für Plasmaforschung, W. GERMANY

Prof. K. Schindler, Ruhr-Universitát Boctum, W. GERMANY

Dr. F. Wagner, (ASDEX), Max-Planck-Institut, W. GERMANY

Librarian, Max-Planck-Institut, W. GERMANY 
